\title{
Institutions and information flows, and their effect on capital flows
}

\author{
Mehmet Pinar $^{*}$, Engin Volkan ${ }^{2}$
}

\begin{abstract}
We examine the empirical role of information flows and institutional quality in explaining the capital flows per capita across countries, and their role in explaining the so-called Lucas paradox -low levels of capital flows to poor countries. The findings of this paper suggest that countries with better institutions and high information flows receive high capital flows, and information flows also provides a partial explanation to the Lucas Paradox. The latter result is significant even after controlling for institutional quality, financial openness and human capital differences across countries, and using instrumental variable for information flows. This paper also examines the indirect effects of institutional quality on capital flows per capita through its impact on information flows and finds that countries with better institutional quality have higher levels of information flow. Accounting this indirect effect is economically important and papers that do not account for this indirect effect of institutions on capital flows per capita would underestimate the effect of institutions on capital flows per capita. Findings of this paper suggest that relatively poorer countries should improve their institutional quality and increase their access to worldwide information and promote investments in communications infrastructure to attract long-term capital flows.
\end{abstract}

Keywords: Capital flows; Information flows; Lucas Paradox; Institutional quality; Telecommunications

JEL Classification: F21; G14

1* Corresponding author: Business School, Edge Hill University, St Helens Road, Ormskirk, Lancashire, L39 4QP, United Kingdom. Phone: +44(0)1695657629 Email:

Mehmet.pinar@edgehill.ac.uk

${ }^{2}$ Marmara University, Acibadem, Kadikoy, 34660, Istanbul. 


\section{Introduction}

The seminal paper of Lucas (1990) questioned why capital does not flow from rich to poor economies even though the neoclassical theory suggests that relatively higher marginal rates of returns in poor countries should attract higher capital flows to these countries. Among many other explanations, differences in institutional quality and political risk are put forward and strongly emphasized. In a seminal paper, Alfaro et al. (2008), AKV hereafter, found that differences in institutional quality across countries is the leading explanation for the Lucas Paradox. This result (institutional quality being the major factor explaining the Lucas paradox) is weakened by Azemar and Desbordes (2013), when they use a natural logarithm of capital flows per capita as the dependent variable rather than the level of capital flows per capita. On the other hand, Slesman et al. (2015), by using a threshold regression model, show a partial explanation for the Lucas paradox. They find that capital flows have positive effects on economic growth if and only if countries have high quality of institutional settings. In other words, their work finds that countries require a threshold level of institutional quality by which capital flows have a positive effect on economic growth ${ }^{1}$.

Beyond the factors mentioned above, a number of papers studied the relationship between information flows and the foreign direct investment (FDI), in general terms capital flows (see e.g., Portes et al., 2001; Choi et al., 2014; Blonigen and Piger, 2014). In particular, it has been argued that the communication and information tools provide a better access to information and minimize the negative effects of asymmetric information. Portes et al. (2001)

\footnotetext{
${ }^{1}$ There are extensive set of papers analysing the factors that explain the capital flows across countries and some of those factors found to be important are the differences in human capital (Caselli and Feyrer, 2007), financial openness (Reinhardt et al., 2013) and domestic fundamentals (Mody et al., 2001), level of moral hazard (Gertler and Rogoff, 1990; Sarno and Taylor, 1999), serial default levels (Reinhart and Rogoff, 2004), and information frictions (Portes and Rey, 2005), among many other factors.
} 
suggest that information flows (by using telephone traffic as a proxy for information flows) could mitigate the information asymmetry and could lead to an increased financial trade. Reynolds et al. (2004) also find a positive relationship between the level of telecommunications infrastructure and FDI suggesting that such investment on infrastructure increases the returns to FDI. Similarly, Francois and Manchin (2013) find that low institutional quality and infrastructure in the south limits their trade levels. In a recent paper, Blonigen and Piger (2014) analyze an extensive list of potential determinants of FDI and find that the host country's communication infrastructure (measured by the number of phone subscribers, internet users and computers) affects FDI decisions. Recently, Choi et al. (2014) find that the internet use mitigates the information asymmetry between countries and increases the volume of crossborder portfolio flows between the United States and other countries. All of the above mentioned papers conclude that information flows increase FDI (capital flows) through increasing productivity and mitigating the asymmetric information. However, to the best of our knowledge, neither the aforementioned papers nor the related literature examine whether the levels of communications infrastructure and information flows might explain the Lucas Paradox or not. This paper is, therefore, a contribution to the literature in this respect.

It has been long established that the infrastructural development levels of countries also play a significant and positive role in their economic growth (see, e.g., Easterly and Levine, 1997). However, development processes of countries through infrastructure growth are shaped by their political and institutional settings (see e.g., Henisz, 2002; Esfahani and Ramirez, 2003) where the economic returns to infrastructure investments are relatively higher in countries with better institutions (see e.g., Straub, 2011 for an extensive review of the mediating effects of political and institutional settings of countries on the economic returns to infrastructure). Even though there exists a theoretical and empirical literature examining the link between infrastructural development and economic growth (see e.g., Calderon and Serven, 2004 for a 
review of theoretical and empirical links between infrastructural development and economic growth), the mechanisms through which infrastructure shapes aggregate economic performance has not been examined. In this paper, we examine some of these potential links. Firstly, we examine the relevance of information flows for the cross-country variation in capital flows per capita. Secondly, we also test the impact of institutional quality on information flows (e.g., Gillanders, 2014 finds that countries with better institutional quality have higher infrastructural development), and its indirect effect on capital flows per capita through its impact on information flows. This latter channel might also provide an additional mechanism for the institutions' effect on long-term economic development (see e.g., seminal papers of Acemoglu, 2001; Rodrik et al., 2004). Hence, this paper will also contribute to the literature to uncover some of the mechanisms through which both institutions and information flows affect capital flows and economic growth.

To test the role of communications infrastructure and information flows, we consider the information flows component from the KOF Index of Globalization. We find that the countries with high levels of information flows, which measures the level of country's openness to global information and communications infrastructure level, attract higher capital flows. Furthermore, we also find that the information flows provide a partial explanation to the Lucas Paradox. This result is significant even after we control for institutional quality proxies, human capital, capital flow restrictions, and asymmetric information and with the use of different sample sizes. In addition to this, we also consider the possibility that the information flows may be endogenous and we used the instrumental variable estimation techniques, and the results are remained to be significant after controlling for the potential endogeneity of the information flows variable. We also find that the institutional quality and financial openness are the other determinants that are found to be significant in most of the specifications where countries with better institutional quality and the ones that are financially more open attract 
higher capital flows. Finally, we find that the institutions have an indirect effect on capital flows per capita through their effect on information flows. This indirect effect of institutions on capital flows per capita is roughly equal to its direct effect highlighting the economic relevance of this indirect link. To put it differently, if the empirical specifications do not account for this indirect effect of institutions on capital flows per capita through their effect on information flows, they would underestimate the effect of institutions on capital flows per capita and therefore its effect on long-term economic development and growth.

The remainder of the paper is as follows. In Section 2, we provide the dataset used in our analysis and relevant literature. Section 3 offers the empirical strategy. Section 4 provides empirical results with different specifications and robustness analysis. Finally, Section 5 concludes.

\section{Data and literature review}

Our dependent variable is the average inflows of portfolio equity and direct investment per capita in 2005 U.S. prices. Similar to the AKV paper, we use the average inflows to capture the long-run effects of the various explanations of the Lucas Paradox. Our period of analysis is between 1982 and 2011. Before averaging the data over the study period, levels of capital inflows are calculated by first-differencing the updated stocks of portfolio equity and direct investment variables from Lane and Milesi-Ferretti (2007). Then the levels of capital flows are divided by population and deflated by the U.S. consumer price index (CPI) levels to bring the values into per capita in 2005 U.S. prices. The population data is obtained from the World Bank's World Development Indicators ${ }^{2}$.

\footnotetext{
${ }^{2}$ World Development Indicators data set does not provide data for Taiwan, hence the population figure for Taiwan is obtained from the World Economic Outlook.
} 
We consider the information flows component from the KOF Index of Globalization (Dreher, 2006 and Dreher et al., 2008). KOF Index of Globalization has been used extensively in the literature to examine the impact of globalization on health outcomes (see e.g., Bergh and Nilsson, 2010a), inequality (see e.g., Dreher and Gaston, 2008; Bergh and Nilsson, 2010b) and economic growth (see e.g., Gurgul and Lach, 2014), and in this paper, we use the information flows component to examine its impact on the FDI. This component is measured in terms of access to the internet, TV and foreign press products. In particular, it is calculated by using the data on the number of internet users (per 100 people), the share of households with a television set, and the sum of exports and imports in newspapers and periodicals (as a percentage of GDP). This component measures the potential flow of ideas and images across the countries, hence serves as a proxy for country's openness to global information and also its investment to telecommunications infrastructure.

We use the natural logarithm of initial income per capita for countries, which is obtained by taking the natural logarithm of the Purchasing Power Parity (PPP) GDP per capita in 1982 from the Penn World Table 8.1 (Feenstra et al., 2015). One of the parameters of interest for this analysis is the coefficient obtained for the initial income per capita. A positive and significant coefficient on initial income per capita implies none of the variables considered in our analysis is able to explain the Lucas Paradox as there is relatively higher capital flows to rich countries. An insignificant coefficient on initial per capita implies that some of the variables provide a partial explanation to the Lucas Paradox since there is no significant relationship between capital flows and initial income per capita after controlling for these factors. Finally, a negative coefficient on initial income per capita after the inclusion of some factors would suggest that these variables are able to provide a full explanation to the Lucas Paradox since capital now flows to poorer countries after the inclusion of factors into the analysis. 
We also use various control variables in our analysis. Institutional setting of countries has been one of the main determinants of the FDI (see e.g., Alfaro et al., 2008; Buchanan et al., 2012, among many others). We use the average of six components of the World Governance Indicators (WGIs) from the World Bank (i.e., voice and accountability, political stability, government effectiveness, regulatory quality, rule of law, and control of corruption) as an institutional quality proxy (Kaufmann et al., 2013). Another factor that have been found to be important is the financial openness (see e.g., Reinhardt et al., 2013; Ahmed and Zlate, 2014). To account for financial openness, we use the restriction to capital mobility proxy from Chinn and Ito (2008), which is constructed as an index to capture the restrictions of financial transactions based on IMF data. This index is normalized to range between 0 and 1 where the higher score represent more financial openness ${ }^{3}$. Human capital is also found to be an important factor in attracting FDI flows since higher human capital increases the returns to investment (see e.g., Cleeve et al., 2015). In order to account for the human capital differences across countries, we use average years of total schooling for population aged 15 and over as a proxy for human capital from Barro and Lee (2010). Finally, to account for asymmetric information across countries, we calculate the distantness measure as a proxy for the asymmetric information similar to that of AKV. Distantness measure is the weighted averages of distances from the main cities of a particular country to the main cities of other countries where we use the GDP shares as weights. GDP shares are coming from the World Economic Outlook data

\footnotetext{
${ }^{3}$ An alternative measure for financial openness is the restrictions component from the KOF index of globalization. However, the correlation coefficient between the Chinn-Ito financial openness index and restrictions component from the KOF index of globalization is positive and significant, i.e., 0.82, for the set of countries used in our analysis and the qualitative findings of this paper are not affected by the use of either measure of financial openness. Among the two measures of financial openness, we use the Chinn-Ito index due to its larger set of country coverage.
} 
set. On the other hand, bilateral distances between main cities of particular country to main cities of other countries come from Head et al. (2010). Distantness measure is also used as a proxy for market access (MA) as countries that are close to other high-income countries, tend to have higher income (see e.g., Redding and Venables, 2004; Liu and Meissner, 2015), with access to the export market found to be the one of the main factors behind this relationship (see Bosker and Garretsen, 2012). In a recent study, Blanco (2012) finds that the surrounding market potential has a positive significant effect on net FDI for the Latin American countries.

In this paper, we use two sets of samples. We use the sample of AKV to replicate their findings with the inclusion of the information flows variable, and we also use the large sample which considers the countries that have a population more than one million over the period of our analysis. Table 1 offers the descriptive statistics for the AKV and large samples ${ }^{4}$. We adjusted the institutional quality and information flows variables to range between zero and ten to allow comparison between these two factors. Higher institutional quality scores represent better governance and institutions, and the higher information flows score implies that a country's openness to global information and telecommunications infrastructure is higher. Average inflows of direct and portfolio equity investment per capita have a mean of 738 and 597 for large and AKV sample countries, respectively. However, countries in the AKV sample has higher mean values for the initial GDP per capita, schooling, institutional quality and information flows variables compared to the mean values of the large sample. Hence, analysis conducted for these two sets of samples might shed a different light into the explanation of the Lucas Paradox ${ }^{5}$

<Insert Table 1 approximately here>

\footnotetext{
${ }^{4}$ See the Appendix Table A1 for the list of countries used in our analysis.

${ }^{5}$ See the Appendix Table A2 for definitions and sources of variables.
} 
Before conducting our empirical analysis, Figs. 1 and 2 plot the relationship between the natural logarithm of average inflows of portfolio equity and direct investment (capital flows) per capita and average information flows for the AKV and large samples, respectively ${ }^{6}$. With both samples, there is a strong positive linear relationship between the natural logarithm of capital flows per capita and average information flows, which confirms the use of log-level regression analysis (see the next section for the empirical strategy) ${ }^{7}$. In the following section, we investigate whether this relationship continue to hold after controlling for various variables and accounting for potential endogeneity of institutional quality and information flows.

\section{$<$ Insert Fig. 1 approximately here> \\ <Insert Fig. 2 approximately here>}

\section{Empirical strategy}

In this paper, we use regression analysis based on the ordinary least squares (OLS) regressions of the natural logarithm of the average inflows of portfolio equity and direct

\footnotetext{
${ }^{6}$ Note that the information flows variable is normalized across the whole panel (i.e., across the countries and years) where the observation in the panel with the highest value is assigned 10, and the remaining ones get normalized scores as follows: (Actual value / Highest value) x 10. This rescaling of information flows variable has no effect on the cross-country variation since the proportional differences between countries with the actual or re-scaled values are the same. However, re-scaling of information flows variable allows us to compare different components' contribution in explaining the variation in capital flows in our empirical analysis. ${ }^{7}$ See Figs. 3 and 4 in the Appendix, which plot the relationship between the capital flows per capita (without taking the natural logarithm of this variable) and average information flows for the AKV and large samples, respectively. Note that the relationship between two variables is not linear with outliers when we do not take the natural logarithm of capital flows.
} 
investment per capita on the natural logarithm of the initial income per capita, average information flows, institutional quality, and other control variables. Regression analysis could be written as:

$\log \mathrm{F}_{\mathrm{i}}=\alpha+\beta \log \mathrm{Y}_{\mathrm{i}}+\gamma_{1} \mathrm{INF}_{\mathrm{i}}+\gamma_{2} \mathrm{INS}_{\mathrm{i}}+\boldsymbol{\delta} \mathbf{X}+\varepsilon_{i}$

where $F_{i}$ is the average inflows of portfolio equity and direct investment per capita between 1982 and $2011, Y_{i}$ is the initial income per capita (i.e., GDP per capita in 1982), $I_{N F}$ is average information flows levels over the same period, $\mathrm{INS}_{\mathrm{i}}$ is the average of six components of the WGIs over the same period, $\mathbf{X}$ is the set of control variables that includes the average financial openness, the logarithm of the average years of schooling (average years of schooling for population aged 15 and over during the same period), and average distantness over the same period, and $\varepsilon_{i}$ is the error term.

In particular, we are interested whether the logarithm of GDP per capita in 1982 is significant or not in order to offer a potential explanation for the Lucas Paradox. The positive significance of the logarithm of GDP per capita in 1982 suggests the presence of the paradox meaning that more capital flows to rich countries. Furthermore, we analyse which of the variables (e.g., institutional quality and/or information flows) makes the logarithm of GDP per capita in 1982 insignificant (negative and significant) when included, hence providing a partial (full) explanation for the Lucas Paradox.

We first start our estimations with the OLS specification. However, an important concern of the capital flows literature is the endogeneity of some of the explanatory variables. To account for the potential endogeneity of the information flows variable, we instrument the information flows with the average level of information flows in neighbouring countries (see e.g., Bergh and Nilsson, 2014 where they use a similar instrumental variable for globalization index). A good instrument variable needs to be correlated with endogenous variable but should 
not be correlated with the dependent variable beyond its effect on endogenous variable. Using neighbouring countries' average outcome for a given variable has been used in the literature as an instrument and found to be a valid approach (e.g., Balgati et al. (2009) use trade openness of neighbouring countries as an instrumental variable for trade openness). Hence, we use average information flows in neighbouring countries as an instrumental variable for information flows variable. Similarly, we also consider the potential endogeneity of the institutions. Hence, we also implement two-stage least squares (2SLS) estimations by using the logarithm of historical European settler mortality rates as an instrumental variable for institutions (e.g., Acemoglu et al., 2001). ${ }^{8}$ However, reliability of this instrumental variable for institutions was criticized due to data benchmarking used in obtaining the settler mortality for some countries and reliability of the data sources (see Albouy, 2012 for further details). In a recent paper, Kelejian et al. (2013) found that the level of institutions in bordering countries affects the institutional development of a country after controlling for various control variables. Hence, we also use the average level of institutions in adjacent countries as instrumental variable for institutions.

\footnotetext{
${ }^{8}$ Acemoglu et al. $(2001,2002)$ argue that the European colonizers faced a different disease environment, which led them to settle (not to settle) and set good (extractive) institutions where settler mortality rates were low (high). They find that the European settler mortality rates shaped different institutions which persisted over time but these rates were not correlated with the income per capita of countries. Hence, the European settler mortality rates are considered to be a valid instrument for institutions. Some other papers that used European settler mortality as instrumental variable for institutions are Rodrik et al. (2004), Bosker and Garretsen (2009), Haggard and Tiede (2011), Acemoglu et al. (2012), Pinar (2015) among many others.
} 


\section{Empirical results}

\subsection{Baseline Estimations}

Table 2 presents the results when we replicate the AKV results with the inclusion of the information flows variable. In the first column, we present the results when we only include the initial per capita in the regressions which suggests that capital flows to rich countries (i.e., the Lucas paradox). In the lines with the AKV estimations, we add institutional quality in column (2) of Table 2 where we find that the institutional quality is positively and significantly associated with capital flows. After the inclusion of the institutions, the coefficient on initial income per capita drops significantly from 1.209 to 0.459 , but it is still significant at the $1 \%$ level. This drop in coefficient on initial income per capita after the inclusion of institutions is something that is expected econometrically since initial income per capita and institutions are highly correlated with each other (see e.g., Acemoglu et al., 2001; Rodrik et al., 2004 for the relationship between institutions and long-run economic development).

\section{<Insert Table 2 approximately here>}

In the third column of Table 2, we report the results when institutional quality is instrumented with the European settler mortality. We have lower number of countries with the instrumental variable estimation as not all countries have data for settler mortality rates. The first stage F-statistic is also well above 10, a cut-off value set by the weak instruments literature (Stock and Yogo, 2005), suggesting that the European settler mortality is a strong instrument for institutions. Qualitatively, the results obtained through 2SLS estimates are similar to those obtained with the OLS estimation. However, after the severe criticisms to the settler mortality data by Albouy (2012), we also use average institutional quality of bordering countries as an alternative instrumental variable for institutions. Column (4) of Table 2 reports the results when we use this alternative instrumental variable for institutions where the results are roughly 
similar to those obtained with the OLS estimation (see column (2) of Table 2) ${ }^{9}$. In column (5), we include additional control variables, namely schooling, financial openness and distantness measure. After controlling for these factors, institutional quality is still a significant factor explaining the variation in capital flows. In all these specifications (i.e., findings that are reported in columns (2)-(5)), both institutional quality and initial income per capita is significant at the $1 \%$ level, confirming the findings of Azemar and Desbordes (2013), which suggest that the Lucas paradox is not explained when log-log specification is used for the estimations (i.e., when the relationship between the natural logarithm of average capital flows per capita and the natural logarithm of the initial GDP per capita is considered).

In column (6) of Table 2, we now include information flows component from the KOF Index of Globalization by excluding the institutional quality from our analysis since institutional quality is the only significant variable beyond initial GDP per capita in explaining variation in capital flows and we would like to examine the effect of inclusion of information flows into the analysis. We find that information flows affect capital flows positively and significantly at the $1 \%$ level. Furthermore, when information flows variable is included to the regressions, initial GDP per capita becomes insignificant. In other words, not only information flows variable is important determinant for capital flows but also it provides a partial explanation for the Lucas paradox ${ }^{10}$. Finally, in column (7), we include institutions, information flows and other control variables. Both coefficients on information flows and institutional quality are positive and significant at the $1 \%$ level, suggesting both factors explain the variation in capital flows. Both of the coefficients on institutions and information flows in column (7) decrease when both variables are controlled for when it is compared to cases when

\footnotetext{
${ }^{9}$ Note that the first stage F-statistic is 51.72, which suggests that average institutional quality of bordering countries is a strong instruments for institutions. See also Kelejian et al. (2013) where they find that the level of institutions in bordering countries affects the institutional development after controlling for various control variables.

${ }^{10}$ For a full explanation to the Lucas paradox, one should expect that the sign of coefficient on initial income per capita to be negative and significant.
} 
either institutions or information is not controlled for (i.e., coefficient on institutions in column (5) and coefficient on information flows in column (6)). Econometrically, decreases in the sizes on both coefficients when both institutions and information flows are not surprising due to the relationship between information flows and institutions. For instance, infrastructural development of countries are shaped by the institutional settings (see e.g., Henisz, 2002; Esfahani and Ramirez, 2003) where countries with better institutions tend to have higher infrastructural development (see, e.g., Gillanders, 2014). In other words, the findings are in the lines with the information flows being a mediator in the link from institutions to capital flows. In other words countries with better institutions have more information flows, but institutions also matter when information flows are controlled for. Finally, when we provide the estimates of information flows (without controlling for institutions) and institutional quality (without controlling for information flows), the decrease in the R-square value is relatively the same when we moved from the case when we controlled for both variables. Hence, the contribution of each component to the explanatory power is roughly the same. In this sub-section, we will test the indirect effect of institutions on capital flows through its effect on information flows but we first examine the effects of institutions and information flows on capital flows per capita when more countries are included into the analysis.

We now replicate the regression analysis to examine whether the relationship between information flows (institutions) and capital flows still holds after the inclusion of more countries into the analysis. Table 3 represents the findings when we use the large sample with the same estimation procedures used in respective columns of Table 2. In column (2) of Table 3, when the institutional quality included in the regression, we find that the institutional quality is a determinant of capital flows, yet it does not explain the Lucas paradox as the coefficient on initial GDP per capita is positive and significant at the $1 \%$ level. Similarly, when the institutional quality is instrumented with the logarithm of the European settler mortality or 
average institutional quality in bordering countries (see columns (3) and (4) of Table 3 for the findings when each respective instrumental variable for institutions is used), the coefficient on initial GDP per capita is still positive and significant. Similar to the findings of Table 2, when we include institutional quality and other control variables into the regression analysis, the coefficient on initial GDP per capita is still positive and significant at the $1 \%$ level (see column (5) of Table 3). Compared to the findings of Table 2, both schooling and financial openness enter to the regressions with expected signs and significantly suggesting that more capital flows to the countries where there is higher human capital and countries that are financially open. In column (6), when we include information flows to the analysis (but exclude the institutions variable), we find the coefficient on information flows is positive and significant at the $1 \%$ level, but the coefficient on initial GDP per capita becomes insignificant when information flows variable is included into the analysis. This suggests that the information flows variable provides a partial explanation to the Lucas paradox. Finally, in column (7), when we include both institutions and information flows to the analysis, both coefficients on institutions and information flows decrease compared to the cases when either institutions or information flows variable is not included into the regression analysis. As mentioned before, the reason why the sizes of the coefficients on institutions and information flows variables drop is that countries with better institutional quality tend to have higher information flows, and the findings are in the lines with the information flows being a mediator in the link from institutions to capital flows.

\section{<Insert Table 3 approximately here>}

To examine the relationship between the institutions and information flows, we regress information flows on institutions and initial income per capita. It is possible that countries with lower information flows might have a lower institutional quality and hence it is important to account for endogeneity problem. Therefore, we also report the findings when the institutional 
quality is instrumented with average institutional quality in adjacent countries. In the lines with the literature, we also control for initial income per capita since it is likely that countries with better development levels have higher information flows. Table 4 demonstrates this relationship between information flows and institutions when the AKV and large samples are used. Columns (1) and (2) reports the results obtained with the OLS and 2SLS estimations with the AKV sample, respectively. The coefficients obtained with the OLS and 2SLS estimations on institutions is roughly the same where a unit increase in institutional quality leads to an increase in information flows by 0.46 . On the other hand, when we get the results with the OLS and 2SLS estimations for the large sample (see the columns (3) and (4) for the results for each respective estimation), we find that the countries with the better institutions are associated with higher levels of information flows. In both cases, F-statistics in the first stage regressions are way above the cut-off value suggesting that average institutional quality in bordering countries is a strong instrument for institutions. These findings are in the lines with the literature where the countries with better institutions tend to have higher information flows and better infrastructure levels.

\section{<Insert Table 4 approximately here>}

Since we obtained the direct and indirect effects of institutions (through its effect on information flows) and direct effects of information flows on capital flows per capita, we can provide some economic implications of these estimates. If we consider the point estimates in column (7) of Table 3 and column (4) of Table 4 as our estimates of various effects, a unit increase in institutional quality leads to an increase in log capital flows per capita by $0.448^{11}$.

\footnotetext{
${ }^{11}$ The total effect of unit increase in institutional quality on capital flows per capita (i.e., 0.448) is obtained by the sum of indirect effect of institutions on capital flows per capita through its effect on information flows (i.e., $0.528 * 0.402=0.212)$ and its direct effect (i.e., 0.236).
} 
Indirect effect of institutions through information flows is almost as large as its direct effect on capital flows (i.e., the indirect and direct effects of institutions on log capital flows per capita are 0.212 and 0.236 , respectively). In other words, the models that only considers the direct effect of institutions on capital flows per capita would underestimate the effect of institutions on capital flows per capita since these models do not account for the indirect impact of institutions on capital flows per capita. Whereas, a unit increase in information flows leads to an increase in log capital flows per capita by 0.402 (see column (7) of Table 3). Considering the coefficients obtained, a standard deviation increase in institutional quality (information flows) (i.e., 2.24 (1.95)) would lead to a roughly $1.00(0.78)$ increase in log capital flows per capita (or $172 \%$ and $118 \%$ increase in capital flows per capita, respectively), suggesting that both of the components' effect on capital flows per capita is economically large.

\subsection{Robustness analysis}

\subsubsection{Unbundling institutions}

For the robustness of our findings and also to unbundle the effects of different institutional quality sub-components on capital flows, we use different institutional quality proxies in the estimation process. In particular, we include sub-components of WGI [i.e., voice and accountability (VA), government effectiveness (GE), political stability (PS), regulatory quality (RQ), rule of law (RL), and control of corruption $(\mathrm{CC})]$ one at a time to account for institutional quality and test whether information flows is still significant after controlling for different institutional quality proxies. The results are presented in Table 5 when we use the large sample ${ }^{12}$. Each column reports the results when respective sub-

\footnotetext{
${ }^{12}$ We conducted a similar application with the AKV sample. The results obtained with the AKV sample are very similar to the large sample case and are available upon request from authors.
} 
component of the WGI is used as institutional quality proxy. Panel A of Table 5 reports the findings when only institutional quality proxy and initial GDP per capita variables are included into the regression analysis. Irrespective of the institutional quality proxy used, both coefficients on institutional quality and initial GDP per capita are positive and significant at the $1 \%$ level. All of the proxies used for institutional quality explain the cross-country variation in capital flows per capita, however, their inclusion does not solve the Lucas paradox (i.e., the coefficient on initial GDP per capita is still positive and significant after the inclusion of different institutional quality proxies). Panel B of Table 5 offers the findings when schooling, financial openness, and distantness measure are included into the analysis as control variables. Both coefficients on institutional quality and initial GDP per capita are significant at the $1 \%$ level after controlling for these factors. Moreover, schooling and financial openness enters to the regressions with the expected sign and significantly irrespective of the use of institutional quality proxy. Yet, the inclusion of additional control variables to the regressions do not offer any solution to the Lucas paradox. Finally, Panel C of Table 5 provides the results when information flows variable is included into the regressions. When the VA, RL and CC are used as a proxy for institutions, initial GDP per capita becomes insignificant after the inclusion of information flows to the analysis suggesting that information flows variable provides a partial solution to the Lucas paradox. However, when the GE, PS and RQ are used as a proxy for institutional quality, initial income per capita is still positive and significant after controlling for all factors suggesting that the Lucas paradox is not solved. Hence, the use of different proxies for institutional quality might lead to a different interpretation of the findings on whether information flows variable provides a partial solution to the Lucas paradox or not. Overall, when we look at the results obtained with the inclusion of all variables (i.e., panel $\mathrm{C}$ of Table 5), we find that the 
financial openness, information flows and institutional quality (with the exception of VA) are the main determinants of capital flows per capita.

$<$ Insert Table 5 approximately here>

We also examine the indirect effects of different institutional quality proxies on information flows where Panels A and B of Table 6 give the results obtained with the OLS and 2SLS estimations for the large sample when we use sub-components of WGI as a proxy for institutions, respectively. With different proxies for institutions, we find that the countries with the better institutions are associated with higher levels of information flows. With the 2SLS estimations, F-statistics in the first stage regressions are way above 10 (i.e., cut-off value for weak instruments) suggesting that average institutional quality with respective proxy in bordering countries is a strong instrument for respective institutional quality proxy. With both estimation techniques, we find that both coefficients on institutional quality proxies and initial GDP per capita are positive and significant at the $1 \%$ level suggesting that the indirect effects of respective institutional quality proxy on capital flows per capita.

<Insert Table 6 approximately here>

By using the significant point estimates in Panel C of Table 5 and Panel B of Table 6 as our estimates of direct and indirect effects of different institutional quality proxies on capital flows per capita, Table 7 offers the total effect of a unit increase in different institutional quality proxies on log capital flows per capita. Except the case of the RQ, the indirect effects of institutional quality proxies through their effect on information flows is greater than their direct effect, which highlights the importance of accounting for the indirect 
effect of institution quality proxies on capital flows ${ }^{13}$. When we look at the economic effect of a unit increase in different institutional quality proxies on capital flows per capita, we find that a unit increase in RQ would provide the largest increase in capital flows per capita (i.e., 64\%). On the other hand, a unit increase in PS, GE, RL, CC, and VA lead to an increase in capital flows per capita by $56 \%, 55 \%, 50 \%, 41 \%$, and $22 \%$, respectively. Hence, the effect of different proxies on capital flows per capita differs and countries aiming to attract higher capital flows might prioritize to improve some aspects of institutional quality as their improvement leads to higher increases in capital flows.

<Insert Table 7 approximately here>

\subsubsection{Unbundling information flows}

Our proxy for information flows variable is also obtained by combining three forms of information flows (i.e., internet users per 100 people, the share of households with a television set, and international newspapers traded as a percent of GDP) and the analysis so far does not identify the type of information flows that matters for capital flows. To do this, we unbundle the effects of different forms of information flows. Table 8 shows the results when we use the three types of information flows when we use the AKV and large samples, respectively. In these regression analysis, we also control for initial GDP per capita, institutions, human capital, and financial openness and the physical distance between countries. To allow comparison between the sub-components of information flows, we

\footnotetext{
${ }^{13}$ The indirect effects of a unit increase in institutional quality proxies on capital flows is calculated by multiplying the respective coefficient on institutional quality proxy in Panel B of Table 6 with the coefficient on information flows in Panel C of Table 5. For instance, indirect effect of a unit increase in VA on capital flows per capita is obtained by $0.366 \times 0.539$.
} 
standardize all types of information flows to range between 0 and 10 where higher values represent higher forms of information flows.

\section{<Insert Table 8 approximately here>}

In models (1) and (4), we used the internet usage proxy for information flows when we use the AKV and large samples, respectively. The coefficients on internet users is statistically significant at the $5 \%$ level with both samples, suggesting the importance of the number of internet users on capital flows per capita. This finding is in the lines with the evidence provided by Choi et al. (2014) where they showed that internet usage play a significant role in transaction of financial assets. In here, we also show that the level of internet users also plays an important role in determining the average inflows of portfolio equity and direct investment. In models (2) and (5), we include the proxy of the share of households with a television set in our analysis when the AKV and large samples are used, respectively. We also find that the increase in television shares also leads to higher capital flows to countries and the coefficients on the television shares are statistically significant at the $1 \%$ and $5 \%$ levels when the AKV and large samples are used, respectively. Even though there is an extensive shift in how people obtain news over the recent years (i.e., there has been a massive increase in the use of digital platforms to obtain information), Papathanassopoulos et al. (2013) find that the most popular choice for news in all countries of their research remained to be the TV news, which may explain the relevance of information flows through this channel in explaining the variation in capital flows. Finally, when we include the international newspapers proxy in models (3) and (6) when the AKV and large samples are used, respectively, we find that variation in international newspapers circulated in the countries does not play a significant role in explaining the capital flows. Using the coefficient estimates from the large sample case, a unit increase in internet users proxy (the share of households with TV sets proxy) leads to an increase in log capital flows per capita 
by $0.365(0.176)$, which is equivalent to an increase in capital flows per capita by $44 \%(19 \%)$. Hence, the effect of information flows on capital flows per capita through internet is relatively larger than the effect through television, which is in the lines with the recent changes in the way that people obtain information through digital platforms.

Finally, with respect to other control variables, we find that the coefficient on institutions variable is always significant and positive irrespective of the type of information flows and sample size, suggesting the importance of institutional quality differences across countries for capital flows per capita ${ }^{14}$. Except in one case (when the share of households with the television set is used in the AKV sample), we also find that initial GDP per capita is positive and significant suggesting that the capital flows to rich countries and none of the variables are able to offer any solution to the Lucas Paradox. Finally, when we use the large sample, we also find that human capital and financial openness differences across the countries also play a significant role in explaining the capital flows.

\subsubsection{Accounting for potential endogeity of information flows}

We also consider the possibility of information flows variable being an endogenous variable where we use the average level of information flows in neighbouring countries as an instrumental variable for information flows. Panel A of Table 9 shows the results when we include average information flows in neighbouring countries to the baseline specification with the information flows variable to examine whether the instrumental variable is correlated with the dependent variable (i.e., average per capita capital flows). This is

\footnotetext{
${ }^{14}$ We should note that institutions also matter for three types of information flows where we find that countries with better institutions tend to have higher usage of internet and shares of households with television sets, and trade higher levels of international newspapers. Hence, institutions play a major role in access to information through different channels.
} 
particularly important for the validity of the instrument variable since a valid instrumental variable should be correlated with endogenous variable but should not be correlated with the dependent variable. Since the information flows in neighbouring countries is not significantly explaining the capital flows per capita directly (Panel A of Table 9), there is no evidence that there is a direct effect of information flows in neighbouring countries on capital flows per capita other than its effect through information flows. Hence, average information flows in neighbouring institutions is a good instrumental variable for information flows. Panel B of Table 9 reports the second stage regression results when information flows variable is instrumented with the average information flows in neighbouring countries. With both sample, the coefficient on income per capita is positive but is not statistically significant, which suggests that information flows variable provides a partial explanation to the Lucas Paradox even after controlling for the potential endogeity of the information flows variable. Finally, Panel C of Table 9 gives the first stage regressions, where the information flows in neighbouring countries explain the information flows significantly when we use the AKV and large samples, respectively ${ }^{15}$.

<Insert Table 9 approximately here>

\section{Conclusions}

Even though the relationship between communications infrastructure and the capital flows examined before, whether the levels of communications infrastructure and information flows might explain the Lucas Paradox or not has not been examined. In this paper, we

\footnotetext{
${ }^{15}$ We also regressed the information flows variable on average information flows in neighbouring countries by excluding the income per capita variable. There is a strong and significant effect of average information flows in neighbouring countries on the information flows variable with R-square levels of 0.63 and 0.74 with the AKV and large samples, respectively.
} 
examined whether the inclusion of information flows variable to the regressions provide an explanation to the Lucas paradox, and we find that the information flows, which measures the level of country's openness to global information and communications infrastructure level, provide a partial explanation to the Lucas paradox. Information flows' partial explanation to the Lucas paradox is in place after controlling for other variables, using different institutional quality proxies, and instrumenting information flows.

Another important contribution of this paper was to examine the effect of institutions on information flows, and its consecutive effect on capital flows per capita. We find that institutional quality of countries not only directly affects the capital flows per capita, but also it has an effect on capital flows per capita through its impact on information flows. In particular, we find that countries with better institutional quality have higher levels of information flows. In other words, the existing literature which includes the institutional quality and information flows as determinants of capital flows in their regressions will underestimate the effect of institutions on capital flows per capita if their models do not account for indirect effect of institutions on capital flows per capita though its impact on information flows. We find that this indirect effect of institutions on capital flows through its impact on information flows is roughly equal to its direct effect, which demonstrates the economic relevance of this indirect link.

Our results may have significant policy implications for policy makers of the developing and emerging countries. Our findings suggest that relatively poorer countries should improve both their institutional quality and also improve their access to worldwide information and promote investments in telecommunications infrastructure to attract long-term capital flows. In particular, improvement in institutional quality of countries would allow these countries to improve their access to worldwide information and investments in telecommunications infrastructure, which would then lead to higher flows of capital per capita. 
In this paper, we also unbundle the effects of institutions and information flows on capital flows per capita. We find that a unit increase in the regulatory quality of countries has the largest effect on the increase of capital flows per capita, and the effects of other subcomponents of institutional quality on capital flows per capita in a decreasing order can be obtained by the improvements in political stability, government effectiveness, rule of law, control of corruption, and voice and accountability. Hence, countries may prioritize the improvements in some aspects of institutional setting if their goal is to attract higher capital flows. Whereas, the governments should prioritize the improvements in internet infrastructure as increase in information flows through this channel leads to relatively larger increases in capital flows compared to other channels of information flows.

Finally, previous studies found that the countries with better institutional quality and telecommunication infrastructure achieve higher levels of income per capita, however, they do not provide specific mechanisms. Our results suggest that information flows might be a channel through which institutions affect long-term development. Furthermore, our results also suggest that capital flows are also another channel through which both institutions and information flows affect long-run development. Hence, a future study analyzing the effects of institutional quality and infrastructure on economic development (growth) should incorporate these indirect channels to have more robust estimates for these factors' effect on economic development (growth).

\section{Acknowledgements}

We thank the editor, Ulrich Kaiser, and an anonymous referee for their detailed and helpful comments that helped us to improve our paper substantially. Authors would also like to thank the participants of Workshop on "Understanding the Capital Flows" for their comments and suggestions. We also would like to thank the British Academy's Newton Advanced Fellowship, 
AF140068, for their financial support. Finally, Mehmet Pinar also acknowledges the financial support of the Research Investment Fund of Edge Hill University.

\section{Appendix}

$$
\begin{aligned}
& \text { <Insert Table A1 approximately here> } \\
& \text { <Insert Table A2 approximately here> } \\
& \text { <Insert Figs. } 3 \text { and } 4 \text { approximately here> }
\end{aligned}
$$

\section{References}

Acemoglu D., Johnson, S., Robinson, J.A., 2001. The colonial origins of comparative development: An empirical investigation. Am. Econ. Rev. 91, 1369-1401.

Acemoglu D., Johnson, S., Robinson, J.A., 2002. Reversal of fortune: Geography and institutions in the making of the modern world income distribution. Q. J. Econ. 117, 12311294.

Acemoglu, D., Johnson, S., Robinson, J.A., 2012. The colonial origins of comparative development: An empirical investigation: Reply. Am. Econ. Rev. 102, 3077-3110.

Ahmed, S., Zlate, A., 2014. Capital flows to emerging market economies: A brave new world? J. Int. Money Financ. 48 (B), 221-248.

Albouy, D.Y., 2012. The colonial origins of comparative development: An empirical investigation: Comment. Am. Econ. Rev. 102, 3059-3076.

Alfaro, L., Kalemli-Ozcan, S., Volosovych, V., 2008. Why doesn't capital flow from rich to poor countries? An empirical investigation. Rev. Econ. Stat. 90, 347-68.

Azemar, C., Desbordes, R., 2013. Has the Lucas Paradox been fully explained?' Econ. Lett. $121,183-187$. 
Baltagi, B.H., Demetriades, P.O., Law, S.H., 2009. Financial development and openness: Evidence from panel data. J. Dev. Econ. 89, 285-296.

Barro, R., Lee, J.-W., 2010. A New Data Set of Educational Attainment in the World, 19502010. J. Dev. Econ. 104, 184-198.

Bergh, A., Nilsson, T., 2010a. Good for Living? On the Relationship between Globalization and Life Expectancy. World Dev. 38 (9), 1191-1203.

Bergh, A., Nilsson, T., 2010b. Do liberalization and globalization increase income inequality? Eur. J. Polit. Econ. 26 (4), 488-505.

Bergh, A., Nilsson, T., 2014. Is Globalization Reducing Absolute Poverty? World Dev. 62, 42-61.

Blanco, L.R., 2012. The spatial interdependence of FDI in Latin America. World Dev. 40 (7), $1337-1351$.

Blonigen, B.A., Piger, J., 2014. Determinants of foreign direct investment. Can. J. Econ. 47, $775-812$.

Bosker, M., Garretsen, H., 2009. Economic development and geography of institutions. J. Econ. Geogr. 9, 295-328.

Bosker, M., Garretsen, H., 2012. Economic geography and economic development in SubSaharan Africa. World Bank Econ. Rev. 26 (3), 443-485.

Buchanan, B.G., Le, Q.V., Rishi, M., 2012. Foreign direct investment and institutional quality: Some empirical evidence. Int. Rev. Financ. Anal. 21, 81-89.

Calderón, C., Servén, L., 2004. The effects of infrastructure development on growth and income distribution. World Bank Policy Research Working Paper No. 3400, World Bank.

Caselli, F., Feyrer, J., 2007. The marginal product of capital. Q. J. Econ. 122, 535-568. 
Chinn, M.D., Ito, H., 2008. A new measure of financial openness. J. Comp. Policy Anal. 10, 309-322.

Choi, C., Rhee, D.-E., Oh, Y., 2014. Information and capital flows revisited: The Internet as a determinant of transactions in financial assets. Econ. Model. 40, 191-198.

Cleeve, E.A., Debrah, Y., Yiheyis, Z., 2015. Human Capital and FDI Inflow: An Assessment of the African Case. World Dev. 74, 1-14.

Dreher, A., 2006. Does Globalization Affect Growth? Evidence from a new Index of Globalization. Appl. Econ. 38, 1091-1110.

Dreher, A., Gaston, N., 2008. Has Globalization Increased Inequality? Rev. Int. Econ. 16 (3), 516-536.

Dreher, A., Gaston, N., Martens, P., 2008. Measuring Globalisation - Gauging its Consequences, Springer, New York.

Easterly, W., Levine, R., 1997. Africa's growth tragedy: policies and ethnic divisions. Q. J. Econ. 112(4), 1203-1250.

Esfahani, H.H., Ramirez, M.T., 2003. Institutions, infrastructure, and economic growth. J. Dev. Econ. 70, 443-477.

Feenstra, R.C., Inklaar, R., Timmer, M.P., 2015. The Next Generation of the Penn World Table. Am. Econ. Rev. 105, 3150-3182.

Francois, J., Manchin, M., 2013. Institutions, infrastructure, and trade. World Dev. 46, 165 175.

Gertler, M., Rogoff, K., 1990. North-South lending and endogeneous domestic capital market inefficiencies. J. Monetary Econ. 26, 2 
Gillanders, R., 2014. Corruption and infrastructure at the country and regional level. J. Dev. Stud. 50(6) 803-819.

Gurgul, H., Lach, L., 2014. Globalization and economic growth: Evidence from two decades of transition in CEE. Econ. Model. 36, 99-107.

Haggard, S., Tiede, L., 2011. The rule of law and economic growth: Where are we?' World Dev. 39, 673-685.

Head, K., Mayer, T., Ries, J., 2010. The erosion of colonial trade linkages after independence. J. Int. Econ. 81, 1-14.

Henisz, W.J., 2002. The institutional environment for infrastructure investment. Ind. Corp. Change 11(2), 355-389.

Kaufmann, D., Kraay, A., Mastruzzi, M., 2013. Worldwide governance indicators project. Available at: http://info.worldbank.org/governance/wgi/index.aspx\#home Kelejian, H.H., Murrell, P., Shepotylo, O., 2013. Spatial spillovers in the development of institutions. J. Dev. Econ. 101, 297-315.

Lane, P.R., Milesi-Ferretti, G.M., 2007. The external wealth of nations mark II: Revised and extended estimates of foreign assets and liabilities, 1970-2004. J. Int. Econ. 73, 223-250.

Liu, D., Meissner, C.M., 2015. Market potential and the rise of US productivity leadership. J. Int. Econ. 96 (1), 72-87.

Lucas, R.E., 1990. Why doesn't capital flow from rich to poor countries? Am. Econ. Rev. 80, 92-96.

Mayer, T., Zignago, S., 2011. Notes on CEPII's distances measures: the GeoDist database. CEPII Working Paper 2011-2025. 
Mody, A., Taylor, M.P., Kim, J.Y., 2001. Modelling fundamentals for forecasting capital flows to emerging markets. Int. J. Finance Econ. 6, 201-216.

Pinar, M., 2015. Measuring world governance: revisiting the institutions hypothesis. Empir. Econ. 48 (2), 747-778.

Portes, R., Rey, H., 2005. The determinants of cross-border equity transaction flows. J. Int. Econ. 65, 269-296.

Portes, R., Rey, H., Oh, Y., 2001. Information and capital flows: the determinants of transactions in financial assets. Eur. Econ. Rev. 45, 783-796.

Redding, S., Venables, A.J., 2004. Economic geography and international inequality. J. Int. Econ. 62 (1), 53-82.

Reinhardt, D., Ricci, L.A., Tressel, T., 2013. International capital flows and development: Financial openness matters. J. Int. Econ. 91, 235-251.

Reinhart, C., Rogoff, K., 2004. Serial default and the 'paradox' of rich to poor capital flows. Am. Econ. Rev. 94, 52-58.

Reynolds, T., Kenny, C., Liu, J., Qiang, C.Z.-W., 2004. Networking for foreign direct investment: the telecommunications industry and its effect on investment. Inf. Econ. Policy $16(2), 159-164$.

Rodrik, D., Subramanian, A., Trebbi, F., 2004. Institutions rule: the primacy of institutions over geography and integration in economic development. J. Econ. Growth 9, 131-165.

Sarno, L., Taylor, M.P., 1999. Moral hazard, asset price bubbles, capital flows, and the East Asian crisis: the first tests. J. Int. Money Financ. 18, 637-657.

Slesman, L., Baharumshah, A.Z., Wohar, M.E., 2015. 'Capital Inflows and Economic Growth: Does the Role of Institutions Matter? Int. J. Finance Econ. 20 (3), 253-275. 
Straub, S., 2011. Infrastructure and development: A critical appraisal of the macro-level literature. J. Dev. Stud. 47(5), 683-708.

Stock, J., Yogo, M., 2005. Testing for weak instruments in linear IV regression, in: Andrews, D., Stock, J.H. (Eds.), Identification and inference for econometric models: Essays in honor of Thomas Rothenberg. Cambridge University Press, New York. 


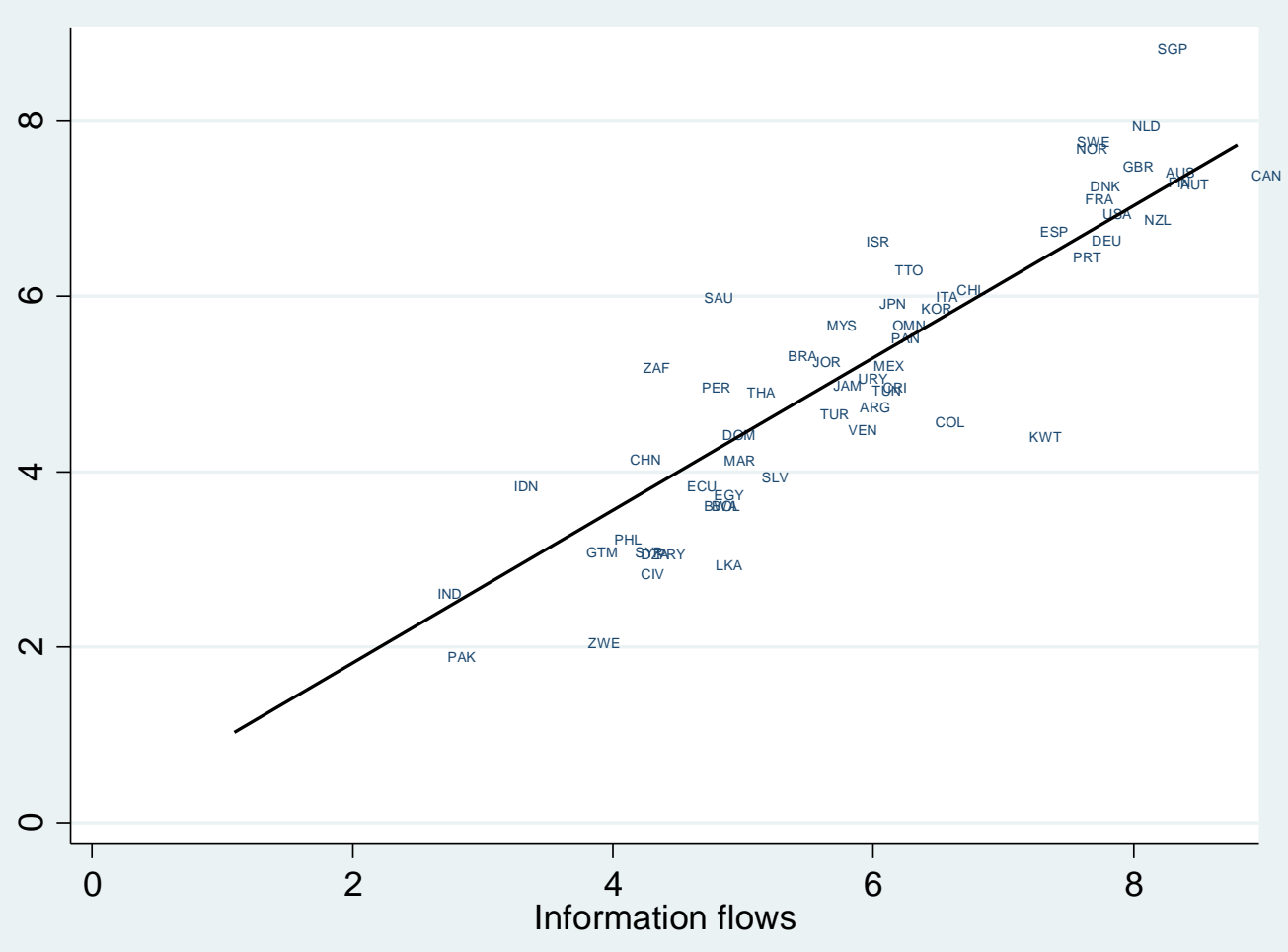

Fig. 1. Capital and information flows with the AKV sample

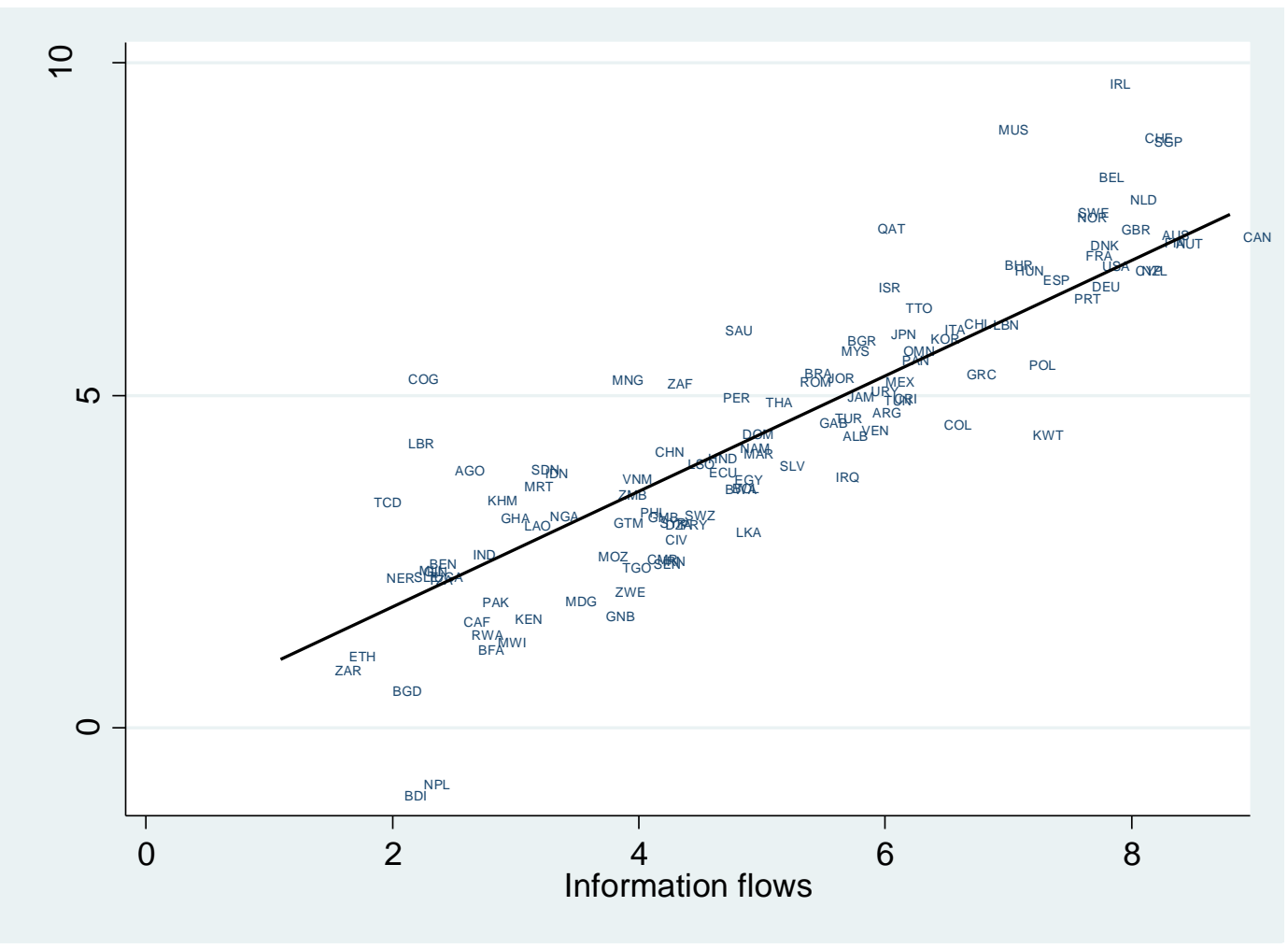

Fig. 2. Capital and information flows with the large sample 


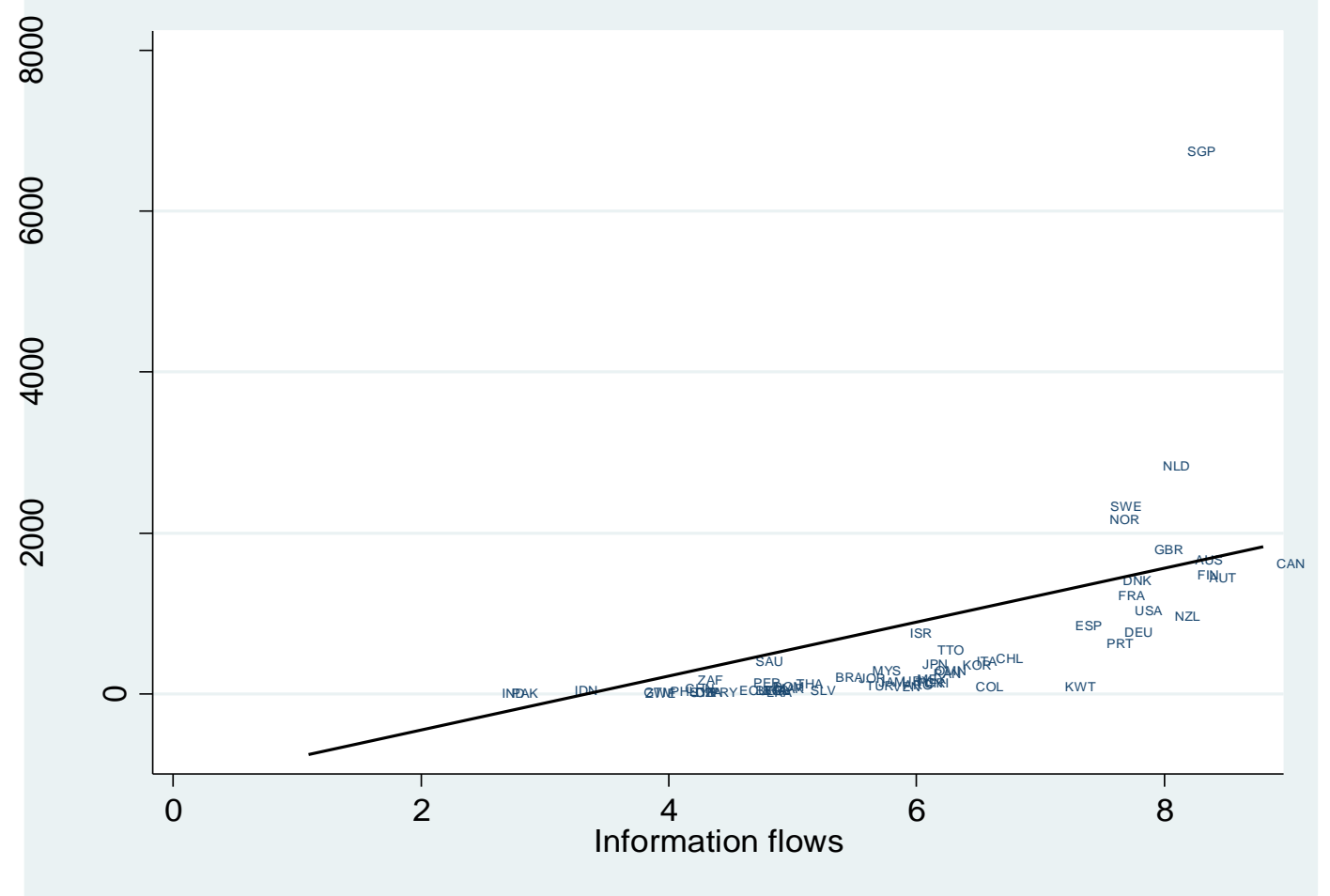

Fig. 3. Capital and information flows with the AKV sample without rescaling capital flows data

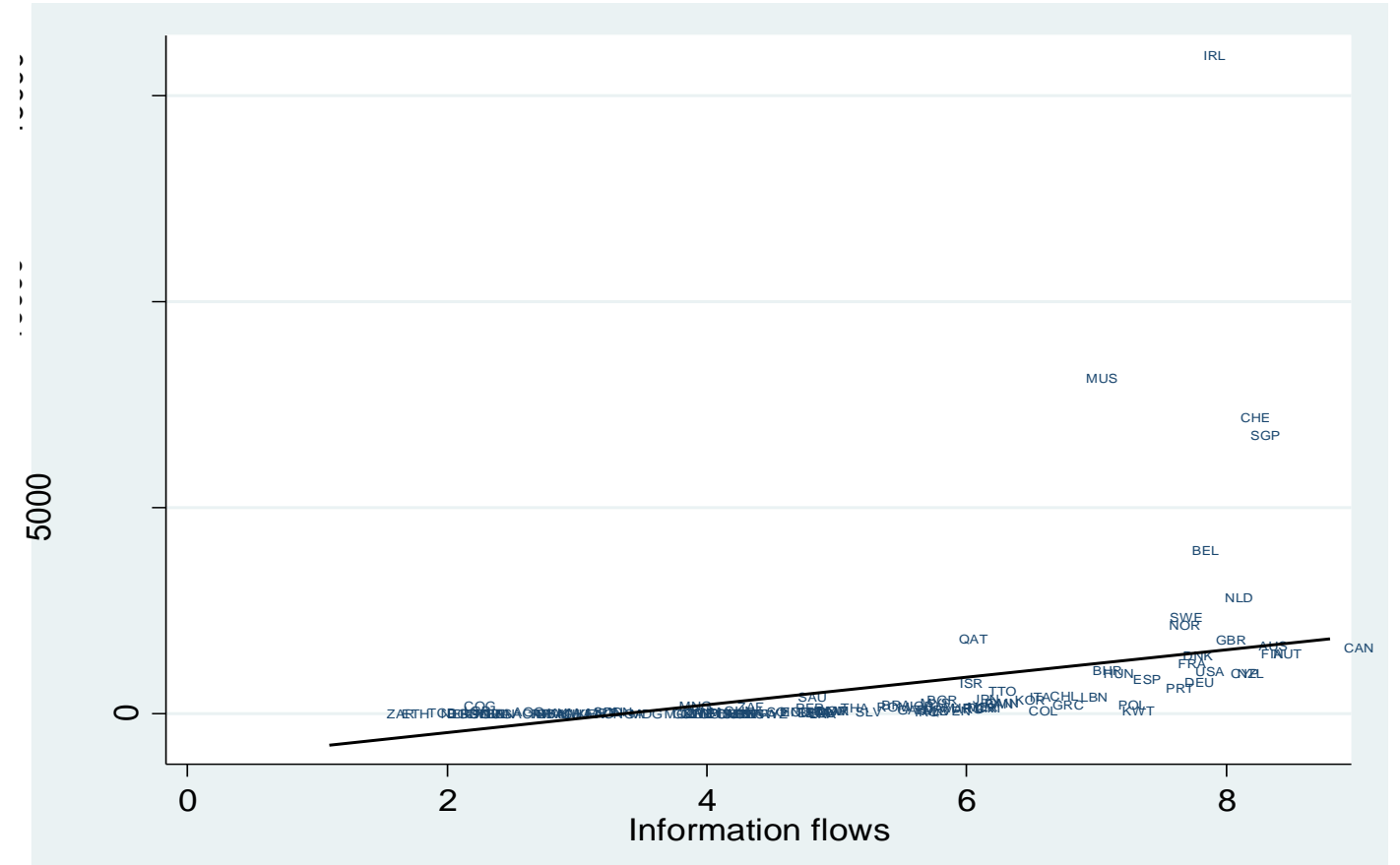

Fig. 4. Capital and information flows with the large sample without rescaling capital flows data 
Table 1

Descriptive statistics.

\begin{tabular}{|c|c|c|c|c|c|c|c|c|c|c|}
\hline & \multicolumn{5}{|c|}{ AKV Sample } & \multicolumn{5}{|c|}{ Large Sample } \\
\hline Variables & Mean & SD & Min & Max & Obs. & Mean & SD & Min & Max & Obs. \\
\hline Information flows & 5.76 & 1.55 & 2.54 & 8.79 & 60 & 4.85 & 1.95 & 1.43 & 8.79 & 118 \\
\hline $\log ($ GDP per capita in 1982$)$ & 8.87 & 1.04 & 5.49 & 10.71 & 60 & 8.36 & 1.24 & 5.49 & 11.44 & 120 \\
\hline Schooling & 7.81 & 2.21 & 3.52 & 12.59 & 59 & 6.80 & 2.72 & 1.23 & 12.59 & 110 \\
\hline Distantness & 8.41 & 2.27 & 5.57 & 14.52 & 60 & 8.20 & 1.87 & 5.57 & 14.52 & 119 \\
\hline
\end{tabular}


Table 2

Replication of the AKV results with information flows.

\begin{tabular}{|c|c|c|c|c|c|c|c|}
\hline & $(1)$ & $(2)$ & (3) & (4) & $(5)$ & $(6)$ & $(7)$ \\
\hline $\log ($ GDP pc in 1982) & $\begin{array}{c}1.209 * * * \\
(0.207)\end{array}$ & $\begin{array}{c}0.459 * * * \\
(0.163)\end{array}$ & $\begin{array}{c}0.750 * * \\
(0.314)\end{array}$ & $\begin{array}{c}0.553 * * \\
(0.264)\end{array}$ & $\begin{array}{c}0.375 * * \\
(0.169)\end{array}$ & $\begin{array}{c}0.159 \\
(0.189)\end{array}$ & $\begin{array}{c}0.224 \\
(0.167)\end{array}$ \\
\hline Institutions & & $\begin{array}{c}0.525 * * * \\
(0.0629)\end{array}$ & $\begin{array}{c}0.382 * * * \\
(0.132)\end{array}$ & $\begin{array}{c}0.459 * * * \\
(0.130)\end{array}$ & $\begin{array}{c}0.450 * * * \\
(0.0806)\end{array}$ & & $\begin{array}{c}0.299 * * * \\
(0.0882)\end{array}$ \\
\hline Log (Schooling) & & & & & $\begin{array}{c}0.587 \\
(0.585)\end{array}$ & $\begin{array}{c}0.999 \\
(0.689)\end{array}$ & $\begin{array}{c}0.443 \\
(0.593)\end{array}$ \\
\hline Financial openness & & & & & $\begin{array}{c}0.341 \\
(0.367)\end{array}$ & $\begin{array}{c}0.711 \\
(0.462)\end{array}$ & $\begin{array}{c}0.276 \\
(0.411)\end{array}$ \\
\hline Log (Distantness) & & & & & $\begin{array}{l}-0.223 \\
(0.369)\end{array}$ & $\begin{array}{c}-0.378 \\
(0.371)\end{array}$ & $\begin{array}{l}-0.143 \\
(0.355)\end{array}$ \\
\hline Information flows & & & & & & $\begin{array}{c}0.623 * * * \\
(0.125)\end{array}$ & $\begin{array}{c}0.365^{* * *} * \\
(0.136)\end{array}$ \\
\hline Observations & 60 & 60 & 34 & 60 & 59 & 59 & 59 \\
\hline R-squared & 0.574 & 0.851 & 0.831 & 0.847 & 0.857 & 0.848 & 0.878 \\
\hline
\end{tabular}

Notes: $*, * *$, and $* * *$ denote significance at the 10,5 , and $1 \%$ level, respectively. Robust standard errors are reported in parenthesis. Dependent variable is the natural logarithm of the average inflows of portfolio equity and direct investment per capita. All regressions include a constant but not reported.

Table 3

Institutions, information flows and capital flows with large sample.

\begin{tabular}{lccccccc}
\hline & $(1)$ & $(2)$ & $(3)$ & $(4)$ & $(5)$ & $(6)$ & $(7)$ \\
\cline { 2 - 8 } Log (GDP pc in 1982) & $1.437 * * *$ & $0.823 * * *$ & $0.821 * * *$ & $0.822^{* * *}$ & $0.516^{* * *}$ & 0.224 & $0.291^{*}$ \\
& $(0.114)$ & $(0.127)$ & $(0.313)$ & $(0.204)$ & $(0.134)$ & $(0.168)$ & $(0.153)$ \\
Institutions & & $0.474 * * *$ & $0.581 * * *$ & $0.474 * * *$ & $0.401 * * *$ & & $0.236^{* * *}$ \\
& & $(0.0660)$ & $(0.221)$ & $(0.127)$ & $(0.0717)$ & & $(0.0671)$ \\
Log (Schooling) & & & & & $0.729 * * *$ & 0.471 & 0.415 \\
& & & & & $(0.266)$ & $(0.338)$ & $(0.298)$ \\
Financial openness & & & & & $0.940 * *$ & $1.411 * * *$ & $0.899 * *$ \\
& & & & & $(0.395)$ & $(0.376)$ & $(0.416)$ \\
Log (Distantness) & & & & & -0.192 & -0.271 & -0.170 \\
& & & & & $(0.394)$ & $(0.384)$ & $(0.371)$ \\
Information flows & & & & & $0.602 * * *$ & $0.402 * * *$ \\
& & & & & & $(0.131)$ & $(0.139)$ \\
Observations & 120 & 120 & 68 & 120 & 109 & 108 & 108 \\
R-squared & 0.673 & 0.789 & 0.761 & 0.789 & 0.809 & 0.812 & 0.826 \\
\hline
\end{tabular}

Notes: $*, * *$, and $* * *$ denote significance at the 10,5 , and $1 \%$ level, respectively. Robust standard errors are reported in parenthesis. Dependent variable is the natural logarithm of the average inflows of portfolio equity and direct investment per capita. All regressions include a constant but not reported. 
Table 4

Relationship between information flows and institutions.

\begin{tabular}{lcccc}
\hline & \multicolumn{2}{c}{ AKV sample } & \multicolumn{2}{c}{ Large sample } \\
\cline { 2 - 5 } & OLS & IV & OLS & IV \\
& $(1)$ & $(2)$ & $(3)$ & $(4)$ \\
\cline { 2 - 5 } Institutions & $0.463 * * *$ & $0.462 * * *$ & $0.441 * * *$ & $0.528 * * *$ \\
& $(0.0647)$ & $(0.0988)$ & $(0.0631)$ & $(0.0698)$ \\
Log (GDP pc in 1982) & $0.469 * *$ & $0.471 * *$ & $0.760 * * *$ & $0.649 * * *$ \\
& $(0.182)$ & $(0.218)$ & $(0.133)$ & $(0.132)$ \\
First-stage F statistics & & 51.72 & & 165.94 \\
Observations & 60 & 60 & 118 & 118 \\
R-squared & 0.816 & 0.816 & 0.835 & 0.830 \\
\hline Notes: *, **, and *** denote significance at the 10, 5, and 1\% level, respectively. Robust \\
standard errors are reported in parenthesis. Dependent variable is average information flows. All \\
regressions include a constant but not reported.
\end{tabular}


Table 5

Institutions, information flows and capital flows with different institutional quality proxies.

Panel A. Institutions as explanatory variable.

\begin{tabular}{|c|c|c|c|c|c|c|}
\hline & $\begin{array}{l}\text { VA } \\
(1)\end{array}$ & $\begin{array}{l}\text { GE } \\
(2)\end{array}$ & $\begin{array}{l}\text { PS } \\
(3)\end{array}$ & $\begin{array}{l}\mathrm{RQ} \\
(4)\end{array}$ & $\begin{array}{l}\mathrm{RL} \\
(5)\end{array}$ & $\begin{array}{l}\mathrm{CC} \\
(6) \\
\end{array}$ \\
\hline $\log (\mathrm{GDP} p \mathrm{p}$ in 1982) & $\begin{array}{c}1.109 * * * \\
(0.123)\end{array}$ & $\begin{array}{c}0.787 * * * \\
(0.127)\end{array}$ & $\begin{array}{c}1.076^{* * *} \\
(0.123)\end{array}$ & $\begin{array}{c}0.815 * * * \\
(0.115)\end{array}$ & $\begin{array}{c}0.867 * * * \\
(0.139)\end{array}$ & $\begin{array}{c}0.892 * * * \\
(0.139)\end{array}$ \\
\hline Institutions & $\begin{array}{c}0.283 * * * \\
(0.0517)\end{array}$ & $\begin{array}{c}0.471 * * * \\
(0.0619)\end{array}$ & $\begin{array}{c}0.376^{* * * *} \\
(0.0739)\end{array}$ & $\begin{array}{c}0.504 * * * \\
(0.0630)\end{array}$ & $\begin{array}{c}0.417 * * * \\
(0.0629)\end{array}$ & $\begin{array}{c}0.375 * * * \\
(0.0572)\end{array}$ \\
\hline $\begin{array}{l}\text { Observations } \\
\text { R-squared }\end{array}$ & $\begin{array}{c}120 \\
0.743\end{array}$ & $\begin{array}{c}120 \\
0.790\end{array}$ & $\begin{array}{c}120 \\
0.750\end{array}$ & $\begin{array}{c}120 \\
0.802\end{array}$ & $\begin{array}{c}120 \\
0.770\end{array}$ & $\begin{array}{c}120 \\
0.761\end{array}$ \\
\hline \multicolumn{7}{|c|}{ Panel B. Institutions and control variables as explanatory variables. } \\
\hline $\log ($ GDP pc in 1982) & $\begin{array}{c}0.637 * * * \\
(0.143)\end{array}$ & $\begin{array}{c}0.504 * * * \\
(0.135)\end{array}$ & $\begin{array}{c}0.531 * * * \\
(0.136)\end{array}$ & $\begin{array}{c}0.569 * * * \\
(0.129)\end{array}$ & $\begin{array}{c}0.508 * * * \\
(0.151)\end{array}$ & $\begin{array}{c}0.462 * * * \\
(0.141)\end{array}$ \\
\hline Institutions & $\begin{array}{c}0.181 * * * \\
(0.0565)\end{array}$ & $\begin{array}{c}0.382 * * * \\
(0.0678)\end{array}$ & $\begin{array}{c}0.324 * * * \\
(0.0737)\end{array}$ & $\begin{array}{c}0.432 * * * \\
(0.0774)\end{array}$ & $\begin{array}{c}0.337 * * * \\
(0.0708)\end{array}$ & $\begin{array}{c}0.302 * * * \\
(0.0558)\end{array}$ \\
\hline Log (Schooling) & $\begin{array}{c}0.900 * * \\
(0.345)\end{array}$ & $\begin{array}{c}0.667 * * \\
(0.283)\end{array}$ & $\begin{array}{c}1.062 * * * \\
(0.285)\end{array}$ & $\begin{array}{c}0.620 * * \\
(0.274)\end{array}$ & $\begin{array}{c}0.871 * * * \\
(0.310)\end{array}$ & $\begin{array}{c}0.988 * * * \\
(0.305)\end{array}$ \\
\hline Financial openness & $\begin{array}{c}1.651 * * * \\
(0.412)\end{array}$ & $\begin{array}{c}1.090 * * * \\
(0.407)\end{array}$ & $\begin{array}{c}1.414^{* * * *} \\
(0.399)\end{array}$ & $\begin{array}{l}0.755^{*} \\
(0.448)\end{array}$ & $\begin{array}{c}1.155^{* * * *} \\
(0.412)\end{array}$ & $\begin{array}{c}1.167 * * * \\
(0.362)\end{array}$ \\
\hline Log (Distantness) & $\begin{array}{l}-0.413 \\
(0.431)\end{array}$ & $\begin{array}{l}-0.136 \\
(0.386)\end{array}$ & $\begin{array}{l}-0.512 \\
(0.399)\end{array}$ & $\begin{array}{l}-0.178 \\
(0.372)\end{array}$ & $\begin{array}{l}-0.0400 \\
(0.427)\end{array}$ & $\begin{array}{l}-0.300 \\
(0.408)\end{array}$ \\
\hline Observations & 109 & 109 & 109 & 109 & 109 & 109 \\
\hline R-squared & 0.772 & 0.806 & 0.800 & 0.813 & 0.796 & 0.794 \\
\hline \multicolumn{7}{|c|}{ Panel C. Institutions, information flows and control variables as explanatory variables. } \\
\hline Log (GDP pc in 1982) & $\begin{array}{c}0.270 \\
(0.166)\end{array}$ & $\begin{array}{l}0.276^{*} \\
(0.154)\end{array}$ & $\begin{array}{l}0.258 * \\
(0.153)\end{array}$ & $\begin{array}{c}0.330 * * \\
(0.153)\end{array}$ & $\begin{array}{c}0.256 \\
(0.158)\end{array}$ & $\begin{array}{c}0.234 \\
(0.160)\end{array}$ \\
\hline Institutions & $\begin{array}{c}0.0740 \\
(0.0522)\end{array}$ & $\begin{array}{c}0.212 * * * \\
(0.0659)\end{array}$ & $\begin{array}{c}0.207 * * * \\
(0.0627)\end{array}$ & $\begin{array}{c}0.251 * * * \\
(0.0814)\end{array}$ & $\begin{array}{c}0.176 * * * \\
(0.0584)\end{array}$ & $\begin{array}{l}0.139 * * \\
(0.0589)\end{array}$ \\
\hline Log (Schooling) & $\begin{array}{c}0.399 \\
(0.318)\end{array}$ & $\begin{array}{c}0.372 \\
(0.303)\end{array}$ & $\begin{array}{l}0.522 * \\
(0.309)\end{array}$ & $\begin{array}{c}0.368 \\
(0.298)\end{array}$ & $\begin{array}{c}0.447 \\
(0.318)\end{array}$ & $\begin{array}{c}0.508 \\
(0.325)\end{array}$ \\
\hline Financial openness & $\begin{array}{c}1.246 * * * \\
(0.389)\end{array}$ & $\begin{array}{c}1.004 * * \\
(0.423)\end{array}$ & $\begin{array}{c}1.065^{* *} * \\
(0.409)\end{array}$ & $\begin{array}{l}0.824 * \\
(0.470)\end{array}$ & $\begin{array}{l}1.025 * * \\
(0.419)\end{array}$ & $\begin{array}{c}1.084 * * * \\
(0.393)\end{array}$ \\
\hline Log (Distantness) & $\begin{array}{c}-0.252 \\
(0.381)\end{array}$ & $\begin{array}{l}-0.136 \\
(0.366)\end{array}$ & $\begin{array}{l}-0.323 \\
(0.364)\end{array}$ & $\begin{array}{c}-0.160 \\
(0.360)\end{array}$ & $\begin{array}{l}-0.0794 \\
(0.389)\end{array}$ & $\begin{array}{l}-0.221 \\
(0.380)\end{array}$ \\
\hline Information flows & $\begin{array}{c}0.539 * * * \\
(0.140)\end{array}$ & $\begin{array}{c}0.422 * * * \\
(0.141)\end{array}$ & $\begin{array}{c}0.459 * * * \\
(0.128)\end{array}$ & $\begin{array}{c}0.393 * * * \\
(0.145)\end{array}$ & $\begin{array}{c}0.460 * * * \\
(0.128)\end{array}$ & $\begin{array}{c}0.474 * * * \\
(0.151)\end{array}$ \\
\hline Observations & 108 & 108 & 108 & 108 & 108 & 108 \\
\hline R-squared & 0.815 & 0.824 & 0.830 & 0.826 & 0.822 & 0.819 \\
\hline
\end{tabular}

Notes: $*, * *$, and $* * *$ denote significance at the 10,5 , and $1 \%$ level, respectively. Robust standard errors are reported in parenthesis. Dependent variable is the natural logarithm of the average inflows of portfolio equity and direct investment per capita. All regressions include a constant but not reported. 
Table 6

Relationship between information flows and different proxies of institutions.

\begin{tabular}{|c|c|c|c|c|c|c|}
\hline \multicolumn{7}{|c|}{ Panel A. OLS Regressions of information flows on institutions } \\
\hline & VA & GE & PS & RQ & RL & $\mathrm{CC}$ \\
\hline & (1) & (2) & (3) & (4) & $(5)$ & $(6)$ \\
\hline \multirow[t]{2}{*}{ Institutions } & $0.291 * * *$ & $0.440^{* * * *}$ & $0.303 * * *$ & $0.468 * * *$ & $0.390 * * *$ & $0.363 * * *$ \\
\hline & $(0.0467)$ & $(0.0599)$ & $(0.0685)$ & $(0.0629)$ & $(0.0588)$ & $(0.0532)$ \\
\hline \multirow[t]{2}{*}{$\log ($ GDP pc in 1982) } & $0.988 * * *$ & $0.726 * * *$ & $1.038 * * *$ & $0.760 * * *$ & $0.798 * * *$ & $0.804 * * *$ \\
\hline & $(0.114)$ & $(0.133)$ & $(0.131)$ & $(0.126)$ & $(0.142)$ & $(0.137)$ \\
\hline Observations & 118 & 118 & 118 & 118 & 118 & 118 \\
\hline R-squared & 0.803 & 0.836 & 0.773 & 0.846 & 0.815 & 0.812 \\
\hline \multicolumn{7}{|c|}{ Panel B. 2SLS Regressions of information flows on institutions } \\
\hline Institutions & $\begin{array}{l}0.366 * * * \\
(0.0584)\end{array}$ & $\begin{array}{r}0.542 * * * \\
(0.0761)\end{array}$ & $\begin{array}{c}0.521 * * * \\
(0.118)\end{array}$ & $\begin{array}{l}0.626 * * * \\
(0.0879)\end{array}$ & $\begin{array}{l}0.495 * * * \\
(0.0728)\end{array}$ & $\begin{array}{l}0.425 * * * \\
(0.0730)\end{array}$ \\
\hline $\log ($ GDP pc in 1982) & $\begin{array}{c}0.902 * * * \\
(0.116)\end{array}$ & $\begin{array}{c}0.588^{* * *} \\
(0.144)\end{array}$ & $\begin{array}{c}0.832 * * * \\
(0.165)\end{array}$ & $\begin{array}{c}0.568 * * * \\
(0.142)\end{array}$ & $\begin{array}{c}0.656^{* * *} \\
(0.149)\end{array}$ & $\begin{array}{c}0.716 * * * \\
(0.155)\end{array}$ \\
\hline First-stage F statistics & 129.39 & 150.63 & 69.07 & 128.76 & 179 & 131.26 \\
\hline Observations & 118 & 118 & 118 & 118 & 118 & 118 \\
\hline R-squared & 0.797 & 0.830 & 0.740 & 0.830 & 0.807 & 0.809 \\
\hline \multicolumn{7}{|c|}{$\begin{array}{l}\text { Notes: } * * *, \text { and } * * * \text { denote significance at the } 10,5 \text {, and } 1 \% \text { level, respectively. Robust standard errors are } \\
\text { reported in parenthesis. Dependent variable is average information flows. All regressions include a constant but } \\
\text { not reported. }\end{array}$} \\
\hline \multicolumn{7}{|c|}{ Table 7} \\
\hline & VA & GE & PS & RQ & RL & $\mathrm{CC}$ \\
\hline $\begin{array}{l}\text { Direct effect on log capital } \\
\text { flows per capita } \\
\text { Indirect effect log capital }\end{array}$ & 0.000 & 0.212 & 0.207 & 0.251 & 0.176 & 0.139 \\
\hline $\begin{array}{l}\text { Indirect effect log capital } \\
\text { flows per capita }\end{array}$ & 0.197 & 0.229 & 0.239 & 0.246 & 0.228 & 0.201 \\
\hline $\begin{array}{l}\text { 10tal erfect log capital } \\
\text { flows per capita }\end{array}$ & 0.197 & 0.441 & 0.446 & 0.497 & 0.404 & 0.340 \\
\hline $\begin{array}{l}\text { Total \% increase in capital } \\
\text { flows per capita }\end{array}$ & $22 \%$ & $55 \%$ & $56 \%$ & $64 \%$ & $50 \%$ & $41 \%$ \\
\hline
\end{tabular}


Table 8

Unbundling the effect information flows on capital flows per capita.

\begin{tabular}{|c|c|c|c|c|c|c|}
\hline \multirow[b]{3}{*}{ Internet users } & \multicolumn{3}{|c|}{ AKV Sample } & \multicolumn{3}{|c|}{ Large Sample } \\
\hline & (1) & (2) & (3) & (4) & (5) & (6) \\
\hline & $\begin{array}{c}0.357 * * \\
(0.164)\end{array}$ & & & $\begin{array}{c}0.365 * * \\
(0.158)\end{array}$ & & \\
\hline TV shares & & $\begin{array}{c}0.215^{* * *} * \\
(0.0733)\end{array}$ & & & $\begin{array}{l}0.176 * * \\
(0.0704)\end{array}$ & \\
\hline International newspapers & & & $\begin{array}{c}0.0289 \\
(0.0470)\end{array}$ & & & $\begin{array}{c}0.0691 \\
(0.0420)\end{array}$ \\
\hline Log (GDP pc in 1982) & $\begin{array}{c}0.277 * \\
(0.143)\end{array}$ & $\begin{array}{c}0.199 \\
(0.135)\end{array}$ & $\begin{array}{c}0.371 * * \\
(0.173)\end{array}$ & $\begin{array}{c}0.370 * * * \\
(0.133)\end{array}$ & $\begin{array}{c}0.347 * * * \\
(0.127)\end{array}$ & $\begin{array}{c}0.505 * * * \\
(0.142)\end{array}$ \\
\hline Institutions & $\begin{array}{c}0.334 * * * \\
(0.0941)\end{array}$ & $\begin{array}{c}0.377 * * * \\
(0.0779)\end{array}$ & $\begin{array}{c}0.429 * * * \\
(0.0852)\end{array}$ & $\begin{array}{c}0.286 * * * \\
(0.0727)\end{array}$ & $\begin{array}{c}0.354 * * * \\
(0.0705)\end{array}$ & $\begin{array}{c}0.379 * * * \\
(0.0684)\end{array}$ \\
\hline Log (Schooling) & $\begin{array}{c}0.219 \\
(0.637)\end{array}$ & $\begin{array}{c}0.550 \\
(0.557)\end{array}$ & $\begin{array}{c}0.621 \\
(0.600)\end{array}$ & $\begin{array}{c}0.549 * \\
(0.283)\end{array}$ & $\begin{array}{c}0.466 \\
(0.293)\end{array}$ & $\begin{array}{c}0.767 * * * \\
(0.286)\end{array}$ \\
\hline Financial openness & $\begin{array}{c}0.279 \\
(0.376)\end{array}$ & $\begin{array}{c}0.317 \\
(0.391)\end{array}$ & $\begin{array}{c}0.332 \\
(0.378)\end{array}$ & $\begin{array}{c}0.640 \\
(0.424)\end{array}$ & $\begin{array}{c}0.839 * * \\
(0.400)\end{array}$ & $\begin{array}{c}0.757 * * \\
(0.355)\end{array}$ \\
\hline Log (Distantness) & $\begin{array}{l}-0.221 \\
(0.360)\end{array}$ & $\begin{array}{l}-0.130 \\
(0.357)\end{array}$ & $\begin{array}{l}-0.225 \\
(0.372)\end{array}$ & $\begin{array}{l}-0.360 \\
(0.371)\end{array}$ & $\begin{array}{c}-0.0873 \\
(0.402)\end{array}$ & $\begin{array}{l}-0.179 \\
(0.389)\end{array}$ \\
\hline Observations & 59 & 59 & 59 & 108 & 108 & 101 \\
\hline R-squared & 0.867 & 0.883 & 0.858 & 0.815 & 0.819 & 0.810 \\
\hline
\end{tabular}

Notes: ***, and *** denote significance at the 10, 5, and $1 \%$ level, respectively. Robust standard errors are reported in parenthesis. Dependent variable is the natural logarithm of the average inflows of portfolio equity and direct investment per capita. All regressions include a constant but not reported. 
Table 9

Instrumental variable regressions of capital flows per capita on information flows.

Panel A: Including the instrumental variable in baseline OLS regressions

Dependent variable: $\log$ (Average capital flows per capita)

\begin{tabular}{|c|c|c|}
\hline & AKV sample & Large Sample \\
\hline \multirow[t]{2}{*}{ Information flows } & $0.860 * * *$ & $0.815 * * *$ \\
\hline & $(0.130)$ & $(0.138)$ \\
\hline \multirow[t]{2}{*}{ Information flows in neighbouring countries } & 0.123 & 0.187 \\
\hline & $(0.111)$ & $(0.135)$ \\
\hline Observations & 60 & 118 \\
\hline R-squared & 0.813 & 0.776 \\
\hline \multicolumn{3}{|c|}{$\begin{array}{l}\text { Panel B: Second-stage regression, information flows instrumented } \\
\text { Dependent variable: } \log \text { (Average per capita capital flows) }\end{array}$} \\
\hline \multirow[t]{2}{*}{$\log ($ GDP per capita in 1982$)$} & 0.205 & 0.313 \\
\hline & $(0.347)$ & $(0.260)$ \\
\hline \multirow[t]{2}{*}{ Information flows } & $0.889 * * *$ & $0.831 * * *$ \\
\hline & $(0.240)$ & $(0.174)$ \\
\hline Observations & 60 & 118 \\
\hline R-squared & 0.816 & 0.787 \\
\hline \multicolumn{3}{|c|}{$\begin{array}{l}\text { Panel C: First-stage regression of information flows on average information flow in neighbouring } \\
\text { institutions } \\
\text { Dependent variable: Average information flows }\end{array}$} \\
\hline \multirow[t]{2}{*}{$\log ($ GDP per capita in 1982$)$} & $0.553 * *$ & $0.674 * * *$ \\
\hline & $(0.251)$ & $(0.156)$ \\
\hline \multirow[t]{2}{*}{ Information flows in neighbouring countries } & $0.519 * * *$ & $0.561 * * *$ \\
\hline & $(0.132)$ & $(0.093)$ \\
\hline Observations & 60 & 118 \\
\hline R-squared & 0.682 & 0.804 \\
\hline
\end{tabular}


Table A1

List of countries.

\begin{tabular}{|c|c|c|c|}
\hline Albania & Ecuador* & Kuwait* & Qatar \\
\hline Algeria* & Egypt* & Laos & Romania \\
\hline Angola & El Salvador* & Lebanon & Rwanda \\
\hline Argentina* & Ethiopia & Lesotho & Saudi Arabia* \\
\hline Australia* & Finland* & Liberia & Senegal \\
\hline Austria* & France* & Madagascar & Sierra Leone \\
\hline Bahrain & Gabon & Malawi & Singapore* \\
\hline Bangladesh & Gambia & Malaysia* & South Africa* \\
\hline Belgium & Germany* & Mali & Spain* \\
\hline Benin & Ghana & Mauritania & Sri Lanka* \\
\hline Bolivia* & Greece & Mauritius & Sudan \\
\hline Botswana* & Guatemala* & Mexico* & Swaziland \\
\hline Brazil* & Guinea & Mongolia & Sweden* \\
\hline Bulgaria & Guinea-Bissau & Morocco* & Switzerland \\
\hline Burkina Faso & Honduras & Mozambique & Syria* \\
\hline Burundi & Hong Kong & Namibia & Taiwan \\
\hline Cambodia & Hungary & Nepal & Tanzania \\
\hline Cameroon & India* & Netherlands* & Thailand* \\
\hline Canada* & Indonesia* & New Zealand* & Togo \\
\hline Central African Rep. & Iran & Niger & Trinidad \& Tobago* \\
\hline Chad & Iraq & Nigeria & Tunisia* \\
\hline Chile* & Ireland & Norway* & Turkey* \\
\hline China* & Israel* $^{*}$ & Oman* & Uganda \\
\hline Colombia* & Italy* & Pakistan* & United Kingdom* \\
\hline Congo, Dem. Rep. & Ivory Coast* & Panama* & United States* \\
\hline Congo, Republic & Jamaica* & Paraguay* & Uruguay* \\
\hline Costa Rica* & Japan* & Peru* & Venezuela* \\
\hline Cyprus & Jordan* & Philippines* & Vietnam \\
\hline Denmark* & Kenya & Poland & Zambia \\
\hline Dominican Rep.* & Korea* & Portugal* & Zimbabwe* \\
\hline
\end{tabular}

Notes: Countries with asterisks $(*)$ are the countries used in the AKV sample. 


\begin{tabular}{|c|c|c|}
\hline \multicolumn{3}{|c|}{$\begin{array}{l}\text { Table A2 } \\
\text { Definition of variables and their sources. }\end{array}$} \\
\hline Variable & Definition & Source \\
\hline Capital flows per capita & $\begin{array}{l}\text { Average inflows of portfolio equity and direct investment per capita between } \\
1982 \text { and } 2011 .\end{array}$ & $\begin{array}{l}\text { Lane and Milesi-Ferretti (2007). } \\
\text { Available via: } \\
\text { http://www.philiplane.org/EWN.html }\end{array}$ \\
\hline Information flows & $\begin{array}{l}\text { This component is measured in terms of access to the internet, TV and foreign } \\
\text { press products. In particular, it is calculated by using the data on the number of } \\
\text { internet users (per } 100 \text { people), the share of households with a television set, and } \\
\text { the sum of exports and imports in newspapers and periodicals (as a percentage of } \\
\text { GDP). This index ranges between } 0 \text { and 10, where higher score means higher } \\
\text { flows of information. }\end{array}$ & $\begin{array}{l}\text { Dreher, } 2006 . \\
\text { Available via: } \\
\text { http://globalization.kof.ethz.ch/ }\end{array}$ \\
\hline Institutional quality & $\begin{array}{l}\text { This is a composite index that averages the six governance indicators from the } \\
\text { World Governance Indicators (WGIs). The index is rescaled to range from } 0 \text { to } \\
\text { 10, where a higher score means better governance measure. }\end{array}$ & $\begin{array}{l}\text { WGIs - Kaufmann et al., } 2013 \\
\text { Available via: } \\
\text { http://info.worldbank.org/governance/ } \\
\text { wgi/\#home }\end{array}$ \\
\hline $\begin{array}{l}\text { Voice and } \\
\text { accountability }\end{array}$ & $\begin{array}{l}\text { Reflects perceptions of the extent to which a country's citizens are able to } \\
\text { participate in selecting their government, as well as freedom of expression, } \\
\text { freedom of association, and a free media. The index is rescaled to range from } 0 \\
\text { to } 10 \text {, where a higher score means better governance measure. }\end{array}$ & $\begin{array}{l}\text { WGIs - Kaufmann et al., } 2013 \\
\text { Available via: } \\
\text { http://info.worldbank.org/governance/ } \\
\text { wgi/\#home }\end{array}$ \\
\hline Political Stability & $\begin{array}{l}\text { Reflects perceptions of the likelihood that the government will be destabilized or } \\
\text { overthrown by unconstitutional or violent means, including politically-motivated } \\
\text { violence and terrorism. The index is rescaled to range from } 0 \text { to } 10 \text {, where a } \\
\text { higher score means better governance measure. }\end{array}$ & $\begin{array}{l}\text { WGIs - Kaufmann et al., } 2013 \\
\text { Available via: } \\
\text { http://info.worldbank.org/governance/ } \\
\text { wgi/\#home }\end{array}$ \\
\hline $\begin{array}{l}\text { Government } \\
\text { effectiveness }\end{array}$ & $\begin{array}{l}\text { Reflects perceptions of the quality of public services, the quality of the civil } \\
\text { service and the degree of its independence from political pressures, the quality of } \\
\text { policy formulation and implementation, and the credibility of the government's } \\
\text { commitment to such policies. The index is rescaled to range from } 0 \text { to } 10 \text {, where } \\
\text { a higher score means better governance measure. }\end{array}$ & $\begin{array}{l}\text { WGIs - Kaufmann et al., } 2013 \\
\text { Available via: } \\
\text { http://info.worldbank.org/governance/ } \\
\text { wgi/\#home }\end{array}$ \\
\hline Regulatory Quality & $\begin{array}{l}\text { Reflects perceptions of the ability of the government to formulate and implement } \\
\text { sound policies and regulations that permit and promote private sector } \\
\text { development. The index is rescaled to range from } 0 \text { to } 10 \text {, where a higher score } \\
\text { means better governance measure. }\end{array}$ & $\begin{array}{l}\text { WGIs - Kaufmann et al., } 2013 \\
\text { Available via: } \\
\text { http://info.worldbank.org/governance/ } \\
\text { wgi/\#home }\end{array}$ \\
\hline Rule of law & $\begin{array}{l}\text { Reflects perceptions of the extent to which agents have confidence in and abide } \\
\text { by the rules of society, and in particular the quality of contract enforcement, } \\
\text { property rights, the police, and the courts, as well as the likelihood of crime and } \\
\text { violence. The index is rescaled to range from } 0 \text { to } 10 \text {, where a higher score } \\
\text { means better governance measure. }\end{array}$ & $\begin{array}{l}\text { WGIs - Kaufmann et al., } 2013 \\
\text { Available via: } \\
\text { http://info.worldbank.org/governance/ } \\
\text { wgi/\#home }\end{array}$ \\
\hline Control of corruption & $\begin{array}{l}\text { Reflects perceptions of the extent to which public power is exercised for private } \\
\text { gain, including both petty and grand forms of corruption, as well as "capture" of } \\
\text { the state by elites and private interests. The index is rescaled to range from } 0 \text { to } \\
10 \text {, where a higher score means better governance measure. }\end{array}$ & $\begin{array}{l}\text { WGIs - Kaufmann et al., } 2013 \\
\text { Available via: } \\
\text { http://info.worldbank.org/governance/ } \\
\text { wgi/\#home }\end{array}$ \\
\hline Distance & $\begin{array}{l}\text { Distance in thousands of kilometres from the capital city of the particular } \\
\text { country to the capital cities of the other countries }\end{array}$ & Mayer and Zignago, 2011 \\
\hline Distantness measure & $\begin{array}{l}\text { The weighted average of the distances in thousands of kilometres from the } \\
\text { capital city of the particular country to the capital cities of the other countries, } \\
\text { using the total GDP shares of the other countries as weights, averages across a } \\
\text { particular time period. }\end{array}$ & Authors calculations \\
\hline Financial openness & $\begin{array}{l}\text { A measure of capital account liberalization where the index ranges between } 0 \\
\text { and 1, where higher score represents more open capital account. This index is } \\
\text { based on IMF's Annual Report on Exchange Arrangements and Exchange } \\
\text { Restrictions. }\end{array}$ & $\begin{array}{l}\text { Chinn and Ito, } 2006 . \\
\text { Updated data available via: } \\
\text { http://web.pdx.edu/ ito/Chinn- } \\
\text { Ito_website.htm }\end{array}$ \\
\hline GDP per capita in 1982 & $\begin{array}{l}\text { Purchasing Power Parity (PPP) GDP per capita in } 1982 \text { from the Penn World } \\
\text { Table 8.1. }\end{array}$ & Feenstra et al., 2015. \\
\hline Schooling & $\begin{array}{l}\text { Average years of total schooling for population aged } 15 \text { and over. Data is } \\
\text { available in 5-year intervals between } 1950 \text { and } 2010 .\end{array}$ & $\begin{array}{l}\text { Barro and Lee, 2010. Available via: } \\
\text { http://www.barrolee.com/ }\end{array}$ \\
\hline
\end{tabular}

